\title{
Soil responses near Delhi ridge and adjacent regions in Greater Delhi during incidence of a local earthquake
}

\author{
H. S. Mandal • P. K. Khan • A. K. Shukla
}

Received: 7 May 2011/Accepted: 19 January 2012/Published online: 4 April 2012

(C) The Author(s) 2012. This article is published with open access at Springerlink.com

\begin{abstract}
In this study, soil response was carried out for the Greater Delhi region. A folded Proterozoic formation was identified as Delhi ridge, passes through its central part along SSW-NNE direction, and appears to be a main geomorphic feature for the study area. The Delhi ridge is an exposed quartzite rock of about 10-100 m wide and $\sim 25 \mathrm{~km}$ long with gentler dipping both toward east and west. We have considered the exposed part as an outcrop side near the ridge axis and the dipping area as rigid base away from the ridge axis for ground motion study during the occurrence of the 25 November 2007 earthquake with magnitude $M_{\mathrm{L}} 4.3$ (Richter scale) that occurred at Delhi-Haryana State boundary. The degree of shaking was very strong and reported major cracks in the buildings near the epicenter area. We have studied the soil response parameters at the surface level, considering horizontally stratified soil layers above rigid base. The equivalent linear method was used for soil response analysis at 25 sites in Greater Delhi area. The peak amplification factors vary from 3.2 to 5.9 and peak resonance frequency varies from 1.2 to $5.3 \mathrm{~Hz}$. The correlation among the peak amplification factor $(A)$ and frequency $(f)$ was empirically established as $A=0.36 f+3.60$. Increasing peak amplification factor was found at sites with increasingly thicker alluvium deposit with lower frequency contains ground motion and vice versa. Seismic zoning map was also reconstructed for peak amplification factors and predominant periods for the study area for the mitigation purposes of earthquake damage. The average shear wave velocity up to $30 \mathrm{~m}$ soil depth is also obtained for site classification. The average velocity to $30 \mathrm{~m}\left[\overline{V_{\mathrm{s}}}(30)\right]$ is a widely used parameter for classifying sites for predicting their potentiality to amplify seismic shaking. A lower value $\left[\overline{V_{\mathrm{s}}}(30)\right]$ thus yields a more conservative estimate of ground motion, which generally increases as $\overline{V_{\mathrm{s}}}(30)$ decreases. Present estimate of $\overline{V_{\mathrm{s}}}(30)$ varies from 315 to $419 \mathrm{~m} / \mathrm{s}$. In this study, we have identified two site classes C and D, as per National Earthquake Hazard Reduction Program. The city planner or engineers can directly use these data for site-specific assessment during retrofitting of the existing structure,
\end{abstract}

H. S. Mandal $(\bowtie) \cdot$ A. K. Shukla

Earthquake Risk Evaluation Center, India Meteorological Department, New Delhi, India

e-mail: himangshu1970@gmail.com

P. K. Khan

Department of Applied Geophysics, Indian School of Mines, Dhanbad, India 
demolition of the old buildings and design a new structure to avoid major destruction of the buildings due to future earthquake.

Keywords Acceleration - Delhi ridge $\cdot$ Soil model $\cdot$ Amplification factor $\cdot$ Peak frequency $\cdot$ Predominant period

\section{Introduction}

Delhi comes under the governance of the National Capital Territory (NCT) and is located in the northwest part of India (Figs. 1,2) and covers an area of $\sim 1,483 \mathrm{~km}^{2}$ with a total population of more than $\sim 17$ million. With globalization, the population along with infrastructure and economy of this city has grown tremendously over the last few years. Delhi is situated in a highly earthquake prone belt near the active Himalayan region. The heavily populated city with a number of artificial structures could be highly prone to damage during incidences of moderate magnitude earthquake from near-field sources. The seismic hazard in Delhi is normally controlled by two tectonic domains with different recurrence characteristics viz. the local domain, occasionally induced by the convergence tectonics along the Himalayan region and largely the western Himalayan tectonic domain. The Delhi region experienced several damaging earthquakes in the historical past. As per the record (Iyengar 1999), Varaha Mihira, who lived in fifth to sixth century, has mentioned the northern India, including Delhi and its surroundings are the significant felt region of severe earthquakes. Oldham (1883) reported that the walls of the fortress and many houses in Delhi were destroyed during the occurrence of the 15 July 1720 Sohna earthquake. He also noted that the aftershock sequences of this earthquake were continued for several weeks to few months. The most disastrous 1803 earthquake having magnitude 7.0 near Mathura (Oldham 1883) was believed to be associated with Mathura Fault, created havoc damage in Delhi area. Tandon and Choudhury (1966) and Iyanger (2000) have also mentioned damage to the Qutub Minar in Delhi during this 1803 earthquake. This earthquake was felt in a very large area and even took 23 human lives in Bulandshahar in western Uttar Pradesh. Another event known as Gurgaon earthquake with magnitude $\sim 6.0$ that occurred on 27 August 1960 near Sohna (Srivastava and Somayajulu 1966) caused minor damages to property and injuries to about 50 persons in Delhi region. On 28 July 1994, an event of local magnitude 4.0 caused minor damage to the minarets of Jamma Masjid (Iyengar and Ghosh 2004). Delhi was not only affected by local earthquakes, regional moderate to large magnitude earthquakes occasionally also created damages to buildings as reported by Mahajan et al. (2010).

Various efforts were undertaken at government level; many studies in the past have been carried out for the estimation of seismic hazard and microzonation of the Delhi region. Most of the seismic hazard studies involved the estimation of peak ground acceleration (PGA) using various ground motion prediction equations (GMPEs). PGA values for 475 years of return period estimated by Agrawal and Chawla (2006) were reported to be in the range of $0.12-0.17 \mathrm{~g}$ and by Sharma et al. (2003) for 225 years of return period between 0.15 and $0.34 \mathrm{~g}$. Iyengar and Ghosh (2004) estimated the PGA values for 2,500 years of return period between 0.18 and $0.24 \mathrm{~g}$, which was the highest in the northwest part of Delhi. Apart from these studies, informations involving the ground shaking site-effects studies by Mukhopadhyay et al. (2002), site-specific microzonation study through 2D modeling of SH and P-SV waves by Parvez et al. (2004), estimation of earthquake hazard in Greater Delhi area by Iyengar and Ghosh (2004), seismic 


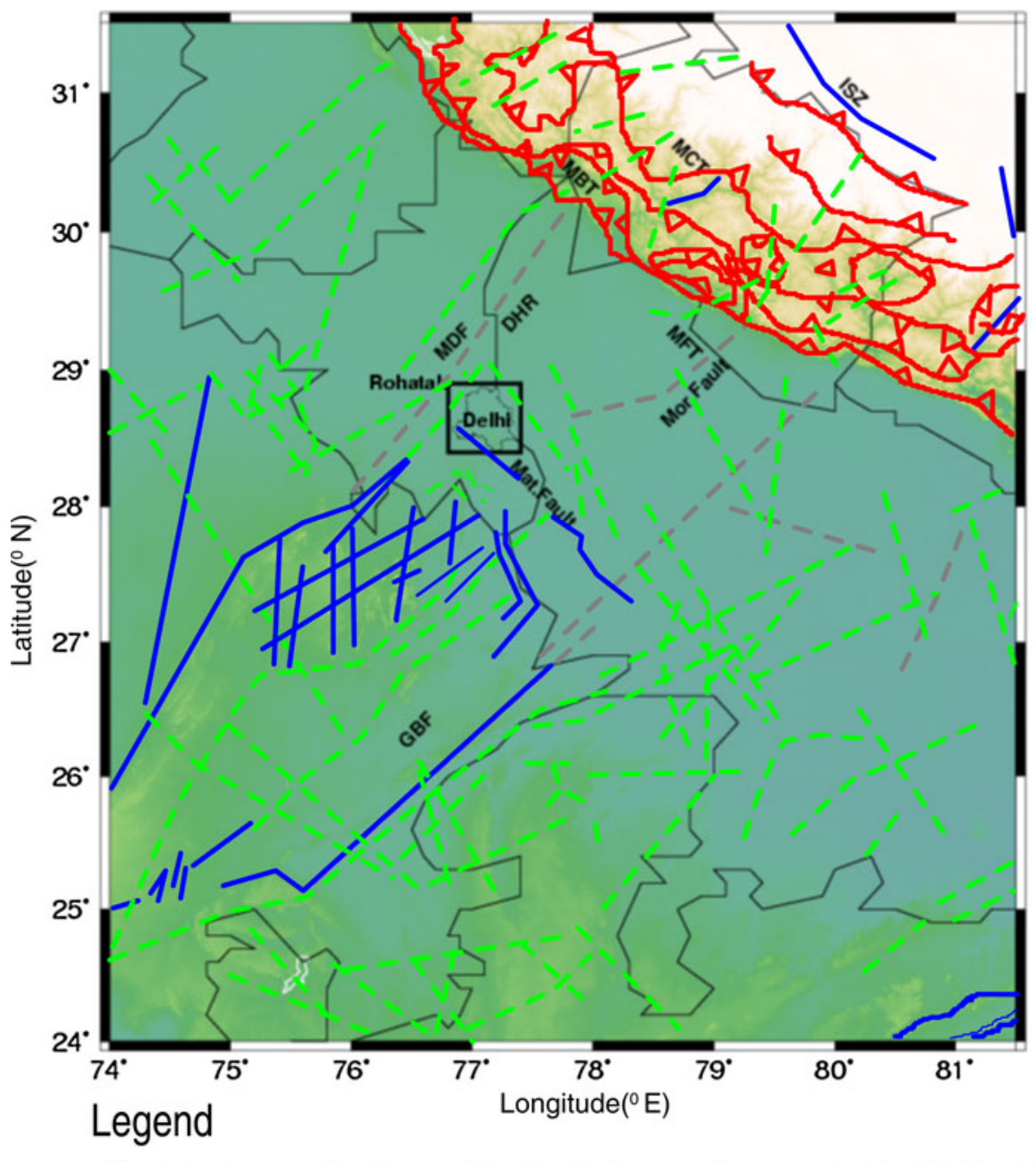

$\wedge$ Thrust_— Fault -- Subsurface Fault -- -Lineaments $\mathcal{N}$ State Boundary

Fig. 1 Map illustrating the detailed tectonic setup of Delhi and surrounding regions (after Joshi and Sharma 2011). MBT Main Boundary Thrust, MCT Main Central Thrust, MFT Main Frontal Thrust, MDF Mahendragarh-Dehradun Fault_-Delhi-Hardwar ridge, GBF Great Boundary Fault, ISZ Indus Suture Zone, Mor-Fault, Moradabad Fault; Son-Fault, Sohna Fault, DHR Delhi-Hardwar Ridge; Mat-Fault, Mathura Fault

microzonation studies by Rao and Satyam (2005), and first-order seismic microzonation map using GIS by Mohanty et al. (2007) provided extensive database for seismic hazard assessment for Delhi and adjoining regions. However, no detail studies were ever being performed for understanding the frequency-dependent soil response as well as the site classification in compliance with the National Earthquake Hazard Reduction Program (NHERP 2000) of USA. This study is significant because of the drastic amplification of the seismic waves in the overlying low-velocity zone those are coming through the interface of strong velocity contrast from the underlying high-velocity zone. It was appreciated in the literature (Kanai et al. 1956; Gutenberg 1957) that the amplitude of seismic waves 


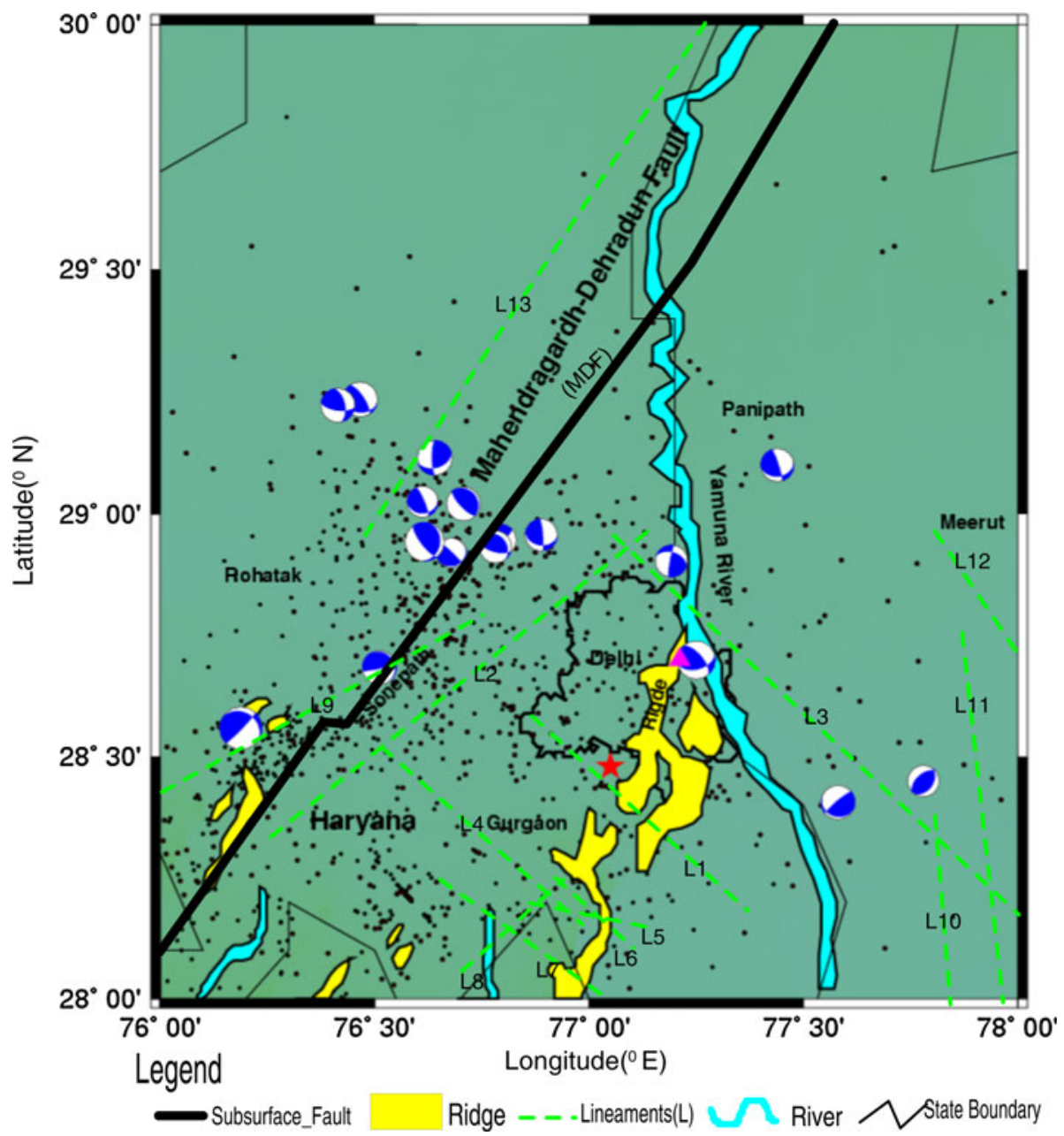

Fig. 2 Map showing the seismotectonic setup of Delhi and surroundings regions (after Dasgupta et al. 2000). Note the locations of the main localities viz. Delhi, Rohotak, Sonepat, Gurgaon, Meerut, and Panipat in respect of Delhi ridge, elongated along NNE-SSW and passing near the center of Delhi territory. Also note the locations of the major fault (e.g., Mehendragardh-Dehradun) and many lineaments (L) crossing the Capital Delhi. Small dots represent the locations of historical earthquakes with magnitude $2.0<M \leq 4.0$. The beach balls indicate the fault plane solutions of the earthquakes. Red star indicates the epicenter of 25 November 2007 an earthquake of magnitude $M_{\mathrm{L}} 4.3$ that ruptured along the lineament L1 (i.e., Sonha fault) in the Broader of Delhi and Haryana State. The gray triangle is a Strong Motion Accelerogram (SMA) recording station near Delhi ridge (light green)

approaching the Earth's surface is magnified by passage through surficial layers of low impedance (Fig. 3). Layer resonances and near-surface impedance gradients are the main factors that cause soil amplification in a simple horizontally layered structure (Haskell 1960; Murphy et al. 1971; Shearer and Orcutt 1987). The importance of soil amplification has clearly been demonstrated for the Mexico earthquake of 19 September 1985 by Seed et al. (1988). Significant damage during the 17 October 1989 Loma Prieta (California) earthquake occurred in areas of San Francisco and Oakland underlain by poor soil 


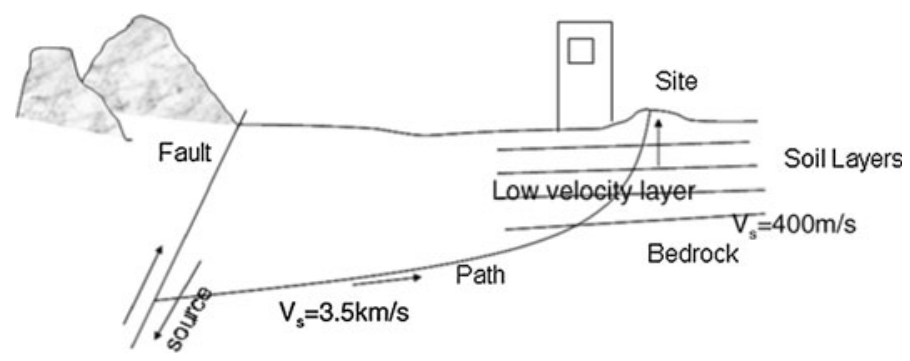

Fig. 3 Diagram represents the seismic wave approaching the earth surface through different geological and geomorphologic medium (after Kramer 1996). It indicates that earthquake rupture takes place at a depth in higher velocity medium, and the released seismic wave propagates through a medium of high-velocity layer $(3,500 \mathrm{~m} / \mathrm{s})$ to engineering bedrock of average shear wave velocity layer (i.e., $\left.400 \mathrm{~m} / \mathrm{s}<\overline{V_{\mathrm{s}}} \leq 750 \mathrm{~m} / \mathrm{s}\right)$. This finally reaches at the top surface through low-velocity soil layers resulting deformation of surficial soil layers and disaster on surface structures

conditions (Borcherdt and Glassmoyer 1992). Benuska (1990) reported that deep clay deposits in the underlying layers caused severe damage in San Francisco Bay and Oakland area through amplification of ground motion. Generally, the seismically induced dynamic loading to the soft soil leads to nonlinear soil behavior, and moreover, the dependence of soil response on strain amplitude became a standard assumption in the geotechnical field (Finn 1991). Evidence of nonlinear site response in seismological observations has appeared over the last 10 years due to an increase in the number of permanent strong motion arrays and an improvement in data quality. Delhi, the capital city is not only situated in the earthquake prone area, but also lies on the thick alluvium soil deposit of river Yamuna. On 25 November 2007, an earthquake of local magnitude $M_{\mathrm{L}} 4.3$ (Richter scale) occurred in the early morning (11:13 UTC) in the Border region of Delhi-Haryana (Fig. 6). The degree of shaking was so strong that most of the buildings located on the thick alluvium sites and near to the epicentral region suffered cracks. This earthquake has been recorded by a strong motion recorder at a site of about $20 \mathrm{~km}$ far from the epicentral region at Delhi Seismic Observatory Ridge. It is understood that the degree of shaking normally depends upon the variable soil layer thickness overlying engineering bedrock rocks (Fig. 3). We thus considered the earthquake as the outcrop source for input ground motion in soil response analysis at 25 different sites using equivalent linear method to compute soil frequency-dependent amplification characteristic over the study area. This study, we have thus addressed the soil amplification with frequencies using geotechnical model, that is, equivalent linear method (ELM). We also have examined the site behavior considering average velocity for $30 \mathrm{~m}$ thick soil using National Earthquake Hazard Reduction Program (NHERP-2000) of USA (Table 4).

\section{Seismotectonics}

Delhi is located between latitude $28.24^{\circ}$ and $28.87^{\circ} \mathrm{N}$ and longitude $76.50^{\circ}$ and $77.33^{\circ} \mathrm{E}$ (Figs. 1,2) to the southwest of the western Himalaya. The terrain of Delhi is flat in general except for the NNE-SSW trending elevated ridge, which is an extension of the Aravalli hill and buried under the Yamuna alluvium in the northern parts of Delhi. River Yamuna is another prominent feature of Delhi, enters the city from north and flows southward with an eastern bend near Okhla. This path forms a tri-junction with the Lahore-Delhi, and the 
Delhi-Haridwar ridges. The areas associated with these extended ridges are seismically active and shows sporadic seismicity aligned in NNE-SSW direction, nearly perpendicular to the Himalayan arc. The nearest point from the Main Boundary Thrust (MBT) to Delhi is around $160 \mathrm{~km}$.

A seismotectonic map of Delhi and its surrounding was reconstructed after the Atlas map of Geological Survey of India (Dasgupta et al. 2000) (Fig. 2). The area is characterized by a major fault (F) and few Lineaments (L). The Mahendragardh-Deharadun fault (F) extends toward northwest up to the Himalaya foot hill. Prominent lineaments in the region display three distinct trends viz. NE-SW, NW-SE, and N-S direction. Since 1963, the area around Delhi has been experiencing a series of earthquakes of mild intensity. These are generally followed by thundering sound and many of them were felt at Rohtak, Sonepat, Delhi, Gurgaon, Meerut, and close to Panipat surrounding Delhi. The epicentral locations of these earthquakes lie along the Mahendragardh-Dehradun fault (F) and along the lineaments (L). The fault plane solutions of few earthquakes are shown in Fig. 2. These minor shocks have been studied by Singh (1964), Hukku (1964), Sharma (1965), Srivastava and Somayajulu (1966) and Tandon and Choudhury (1966). Most of the shocks were interpreted to be of shallow focus with epicenter in most cases located west, southwest, and south of Delhi (Delhi-Haryana broader) region. Singh (1964) interpreted these were due to water-logging as a result of which the sandy beds did not permits the subsoil vapor to pass out and cause eruption in the superficial layer leading to frequent tremor. Hukku (1964) attributes these shocks to collapse of limestone cavern that may exist along fault zones in Vindhyan limestones covering the basement rocks. Srivastava and Somayajulu (1966) show that the Sonepat-Delhi-Sohna dislocation is responsible for the frequent earthquakes in and around Delhi city. The open circles in Fig. 6 indicate the epicentral locations of 654 earthquakes with magnitude $\leq 3.0$ occurred in NCT, Delhi and surrounding areas (i.e., National Capital Territory) during the period 2000-2010. These earthquakes were precisely monitored by a Network called Delhi Seismic Telemetry Network run by India Meteorological Department (IMD) since the year 2000.

\section{Dynamic soil response analysis}

The ground is assumed to be composed of elastic material; however, the ground shows nonlinear behavior due to earthquakes loading, and the resulting soil exhibits nonlinear behavior from the small strain $\left(\sim 10^{-3}\right)$. The nonlinear characteristic of the soil is usually called dynamic deformation characteristic. Seed and Idriss (1970) and Hardin and Drenevich (1972a, b) expressed nonlinear characteristic of soil is caused by cyclic loading. Thus, earthquake response analysis widely done on computer code SHAKE (Schnabel et al. 1972), which based on multiple reflection theory and nonlinearity of soil behavior, considered as equivalent linear method where the stress-strain relationship must be linear in solving the equation of motion in frequency domain. Nonlinear hysteretic stress-strain behavior of cyclically loaded soils (Fig. 4) can be approximated by equivalent linear soil properties when the strain level is not large. Since the linear approach requires that the shear modulus and damping ratio be constant for each soil layer, the problem becomes one of determining the values that are consistent with the level of strain induced in each layer. Since the time history of shear strain for a typical earthquake motion is highly irregular with peak amplitude that may only be approached by a few spikes in the record. The harmonic record represents a more severe loading condition than transient record, when their peak values are identical. It is common to characterize the strain level of the transient 


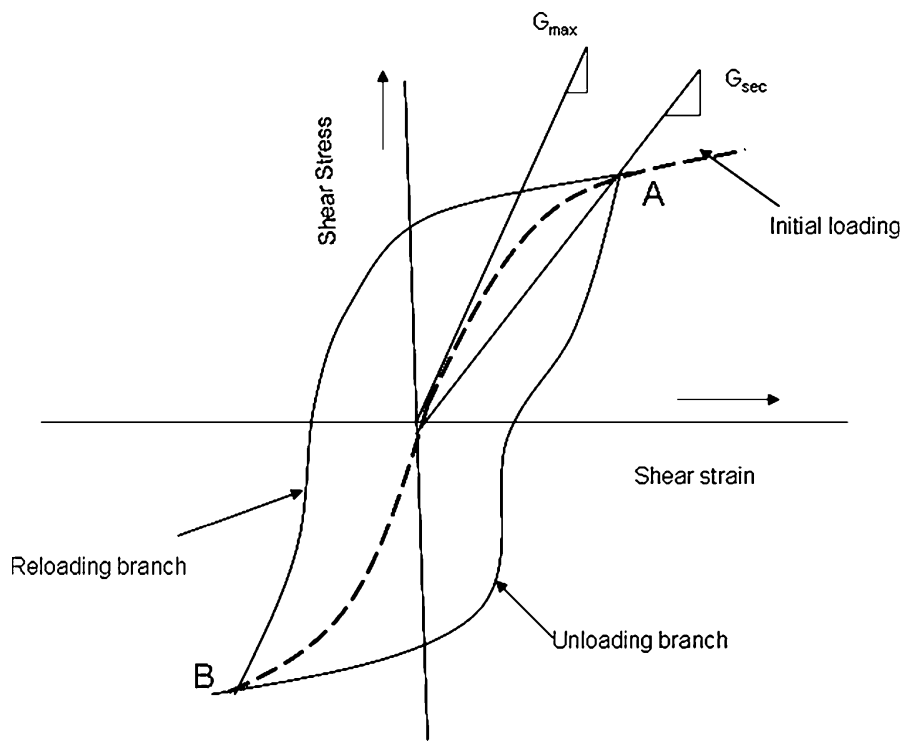

Fig. 4 Plot represents a typical stress-strain relationship for soil in cyclic shear deformation (after Mohammadioun and Pecker 1984). Initial loading curve has a hyperbolic form (broken line). Subsequent unloading and reloading phases track a hysteretic path. Two hysteresis loops constructed according to Massing rules (Erdik 1987) are shown, where $A$ and $B$ mark the Reversal points with the loop. The maximum shear modulus $\left(G_{\max }\right)$ and the secant shear modulus $\left(G_{\mathrm{sec}}\right)$ are obtained from the tangent of stress-strain curve (dotted line). Tangent was drawn between points of origin (low strain) and maximum strain due to failure stress of the sample

record in the terms of an effective shear strain that has been empirically found to be around $65 \%$ of the maximum shear strain.

As the calculated strain level depends on the values of the equivalent linear properties, an iterative procedure is required to ensure that properties used in the analysis are compatible with the calculated strain levels in all layers. To achieve this condition, the following procedure is adopted. Initial estimates of $G$ and $h$ are made for each layer using the following empirical relations.

$$
\begin{aligned}
G & =\rho V_{\mathrm{s}}^{2} \\
h & =\frac{1}{2 Q}
\end{aligned}
$$

where $G$ the shear modulus at low strain, $\rho$ the Bulk density, $V_{\mathrm{s}}$ the shear wave velocity, $h$ the damping ratio and $Q$ the quality factor of shear wave. Equation 1 is widely used and was established from well-log data. Equation 2 was empirically deduced by Fukushima and Midorikawa (1994) for estimating the damping ratio. The estimated $G$ and $h$ values are used to calculate the ground response including time history of shear strain for each layer.

The effective shear strain in each layer is determined by the estimated maximum shear strain. For $j$ th layer, the effective shear strain can be defined as

$$
\gamma_{\text {effective }, j}^{(i)}=R \gamma_{\max , j}^{(i)}
$$

where $R$ is the ratio of effective shear strain to the maximum shear strain. The effective estimated shear strain allows to be chosen as new equivalent linear values $G^{(i+1)}$ and $h^{(i+1)}$ 
Fig. 5 Flow chart of computational program for soil response analysis using equivalent linear method (after Seed and Idriss 1969). $G_{\max }$ and $h_{\text {min }}$ are the initial shear modulus and damping for very low strain under in situ soil condition. $u_{g}$ amplitude of input waveform at the outcrops. The program stops iteration if the difference of shear modulus and damping ratio between previous and current analyses are within the specific range less than $5 \%$ else continued the loop

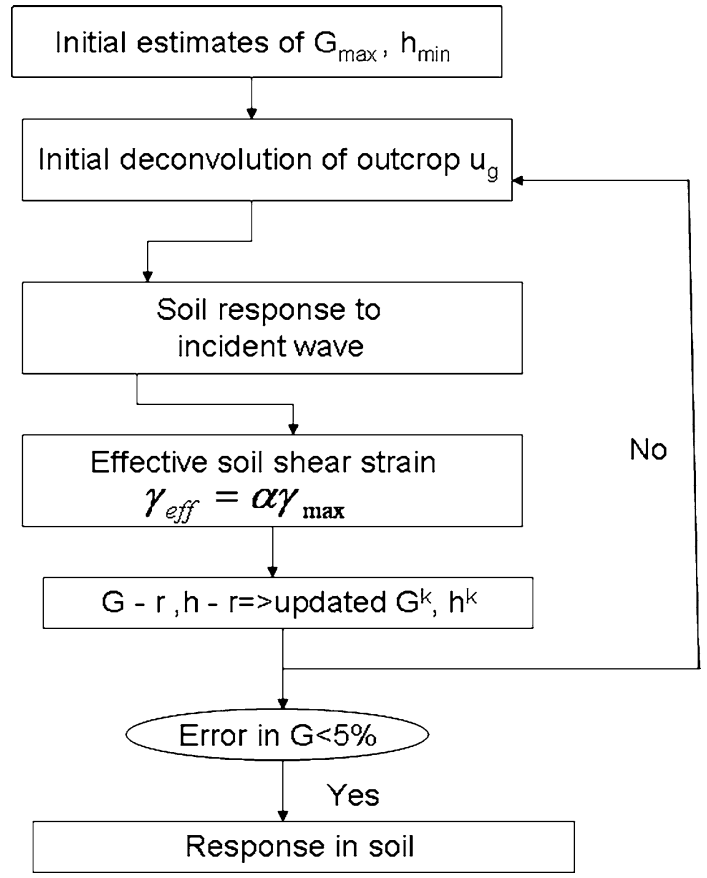

for the next iteration, and the iteration process is continued until the difference between computed shear modulus and damping ratio values in two successive iterations fall below predetermined allowable error (typically $5 \%$ ) in all layers (Fig. 5). This procedure (Schnabel et al. 1972) using the computer code SHAKE is commonly used for onedimensional ground response analysis.

The site classes assessed from shallow shear wave velocity models are important in deriving strong motion prediction equations (Boore et al. 1997), for the reconstruction of maps in compliance of National Earthquake Hazard Reduction Program (NEHRP) site classes (Wills et al. 2000), and moreover, in applications of building codes to specific sites. The average shear wave velocity of the top $30 \mathrm{~m}$ of the Earth, that is, $\overline{V_{\mathrm{s}}}(30)$ was computed through division of $30 \mathrm{~m}$ by the travel time, and the method is widely used in classifying sites in recent building codes and loss estimation (Dobry et al. 2000; BSSC 2001). The $\overline{V_{\mathrm{s}}}(30)$ is obtained from the definition of NEHRP site classes as follows,

$$
\overline{V_{\mathrm{s}}}(30)=\frac{30}{\sum_{i=1}^{n} \frac{H_{i}}{V_{i}}}
$$

where $H_{i}$ and $V_{i}$ are the thickness and velocity for the $i$ th layer and $n$ is the total number of layers.

\section{Data}

A time series acceleration recorded at India Meteorological Department (IMD) Seismic Observatory Ridge (SOR), NCT Delhi (Fig. 7) was used under the study. The maximum 


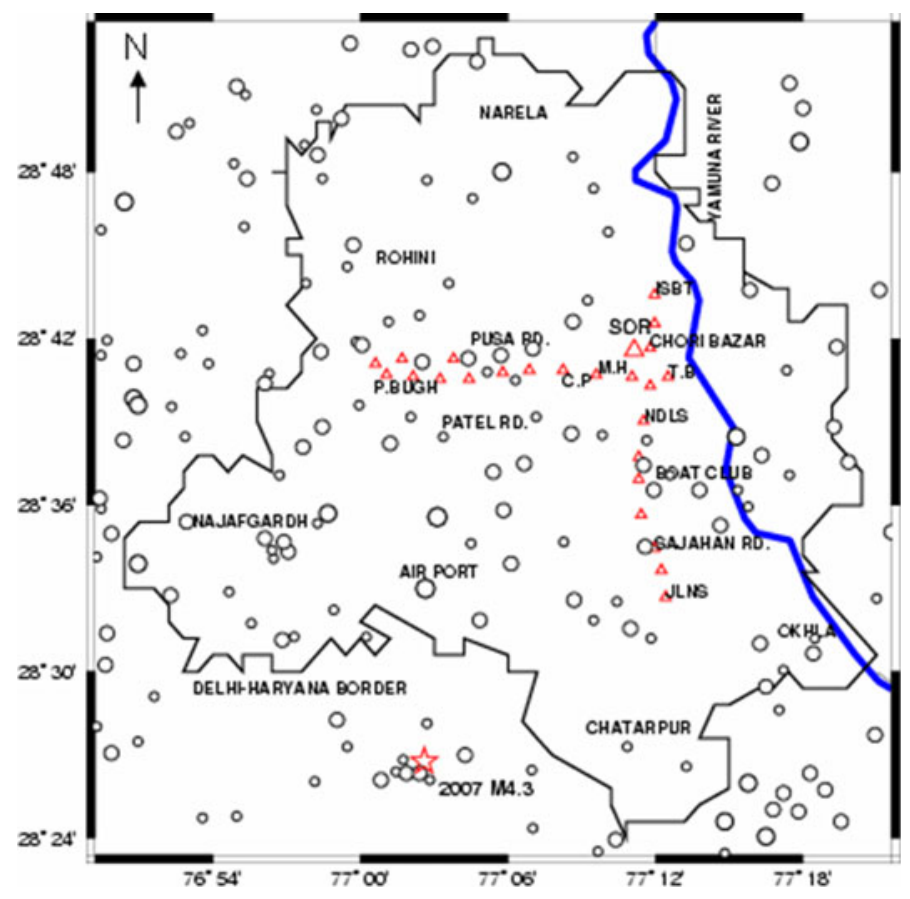

Fig. 6 Map showing the few important localities in NCT Delhi. The red star indicates shallow focal depth local earthquake of magnitude $M_{\mathrm{L}} 4.3$ (in Richter scale) occurred on 25th November, 2007 at 11:13 h UTC near the Delhi-Haryana border. Red triangle shows the location with an earthquake recording Seismic Observatory on Delhi ridge. The other triangles of small size are located about $1-\mathrm{km}$ interval indicate the places where the soil samples down to the depth of $100 \mathrm{~m}$ were taken along two E-W and N-S profiles. The few important locations in greater Delhi are Inter State Bus Terminal (ISBT), Chowri Bazar, Tilak Bridge (TB), New Delhi Railway Station (NDLS), Boat Club, Sajahan Road (Sajahan RD), Jawahar Lal Nehru Stadium (JLNS), Mandi House (MH), Connaught Place (CP), Pusha Road (PR), Patel Road (Patel RD), Punjabi Bagh (PB) and Rohini. Blue line shows the N-S flow of Yamuna River. The small open circles illustrate the locations of epicenters of local earthquakes with magnitude $M_{\mathrm{L}}<3.0$ occurred during the period 2000-2010 in Delhi and surrounding regions

PGA value with $15-20 \mathrm{~s}$ duration in the horizontal component is noted $0.015 \mathrm{~g}$. The full $40.96 \mathrm{~s}$ waveform is used for the estimation. The vertical lithologs and physical soil properties are prepared by integrating the existing borehole report, geophysical survey and the earlier work done by Iyanger (2000), Iyengar and Ghosh (2004), Parvez et al. (2004) and Rao and Satyam (2005). Every $1 \mathrm{~km}$ interval sites are selected to find the soil amplification or de-amplification characteristics in a microscale. The more detailed 25 site locations along (1) East-West direction of spread length $\sim 13 \mathrm{~km}$ and (2) North-South direction spread length $10 \mathrm{~km}$ were chosen (Fig. 6). The soil classification is done as per geotechnical soil code cited as ML for sandy-silt, ML-SM for silty sand, SM for sand, Wt-Qrtz. for weather quazite and Rock for hard rock formation. The physical parameters viz., layer thickness $(H-\mathrm{m})$, shear wave velocity $\left(V_{\mathrm{s}}-\mathrm{m} / \mathrm{s}\right)$, density $\left(\mathrm{g} / \mathrm{cm}^{3}\right)$, quality factors $\left(Q_{\mathrm{s}}\right)$, damping (h \%) and shear modulus are listed in Tables 1 and 2 for East-West and North-South profile, respectively. The minimum damping of in situ soil samples is obtained from the inverse of twice of the quality factor (Fukushima and Midorikawa 1994). The maximum in situ shear modulus $\left(G_{0}\right)$ at very low strain (usually $10^{-6}$ ) is obtained 


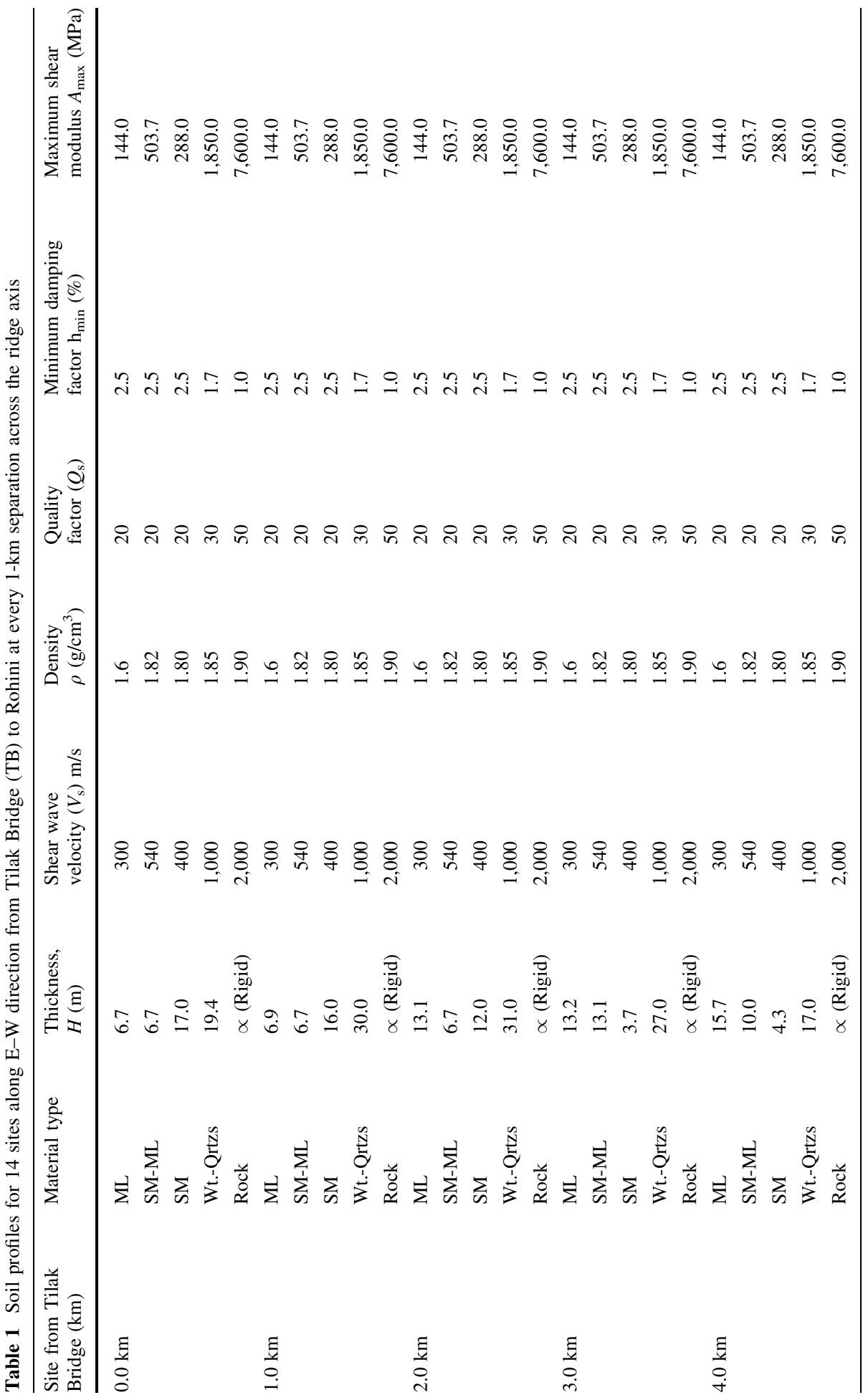

Springer 


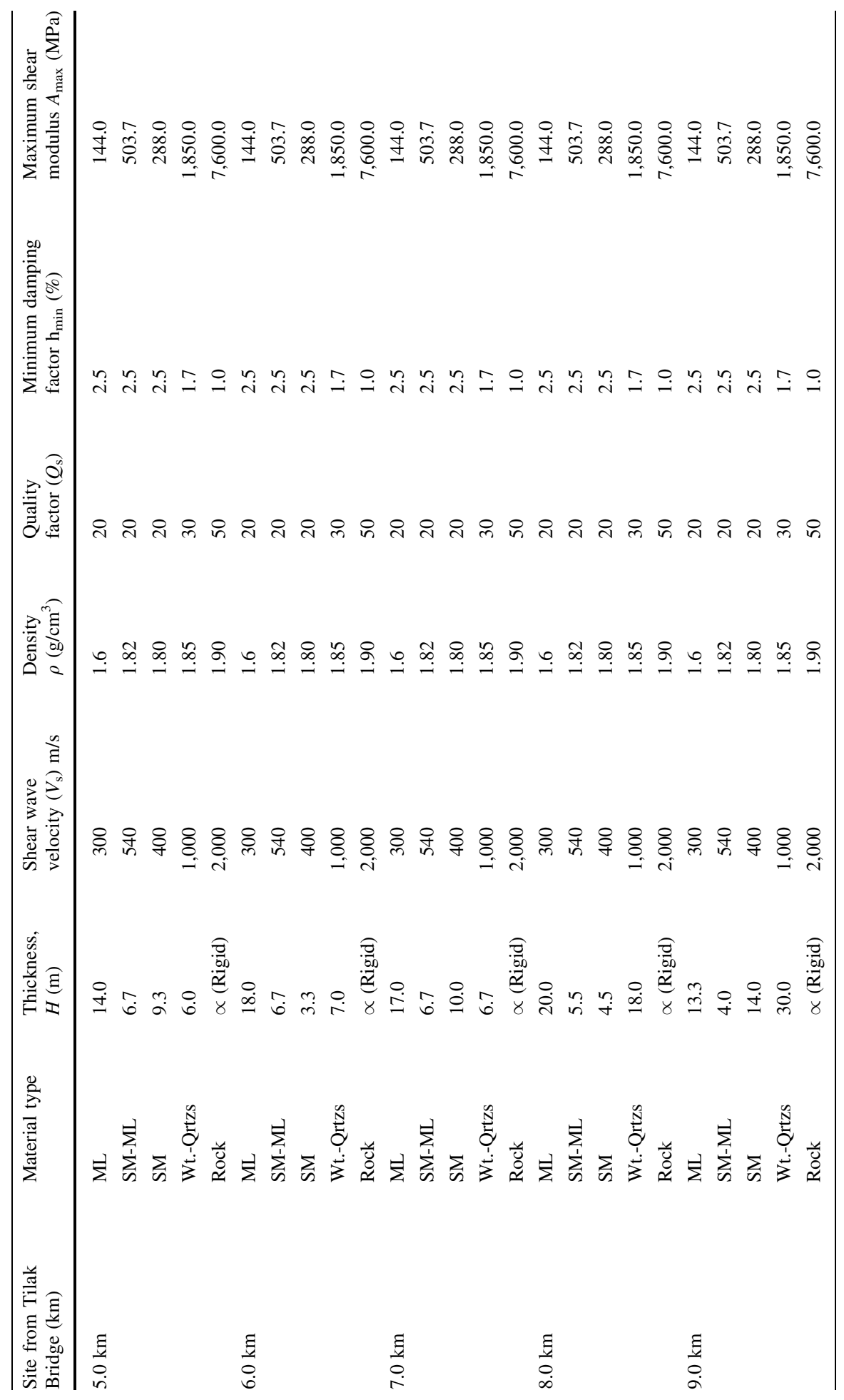




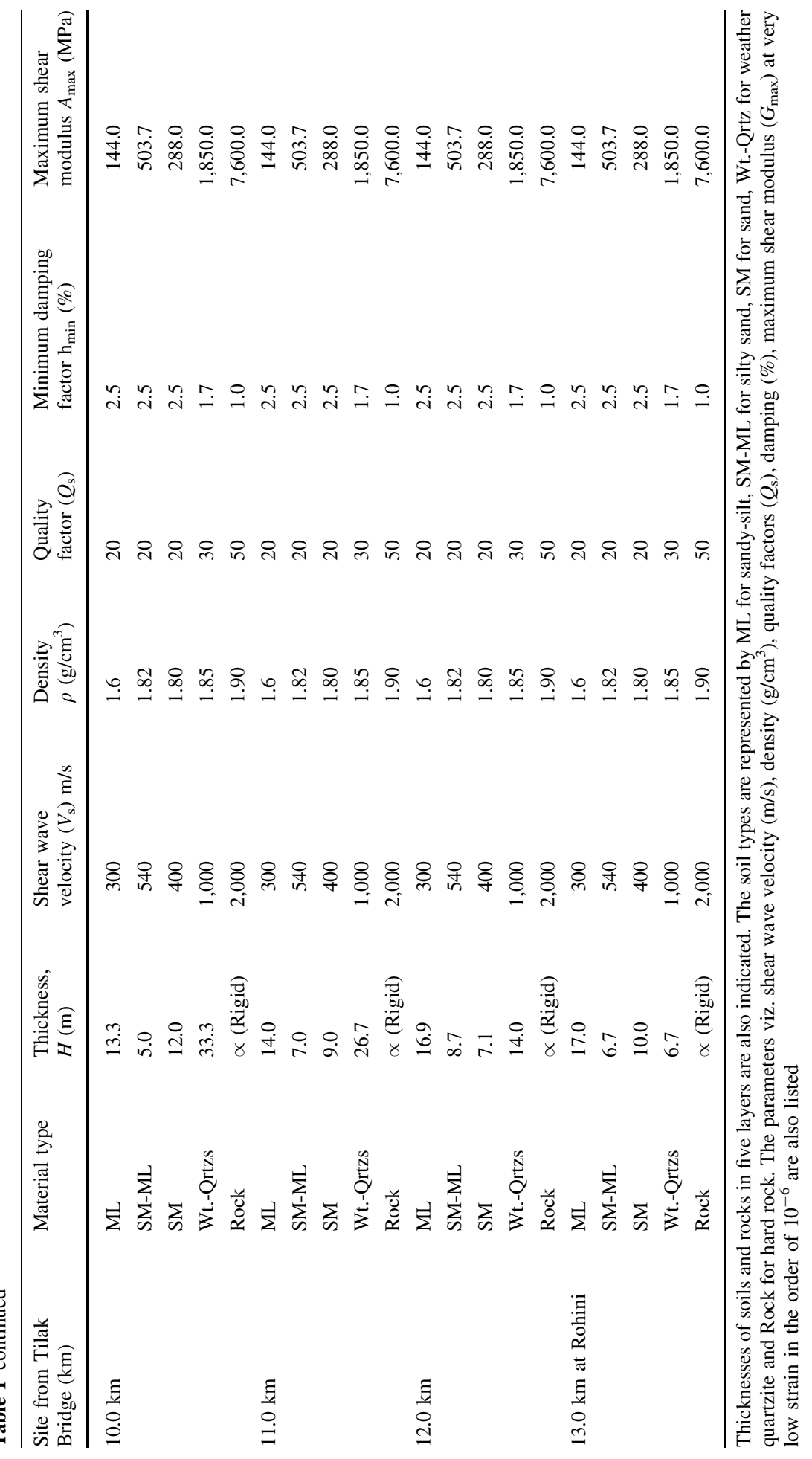

Springer 


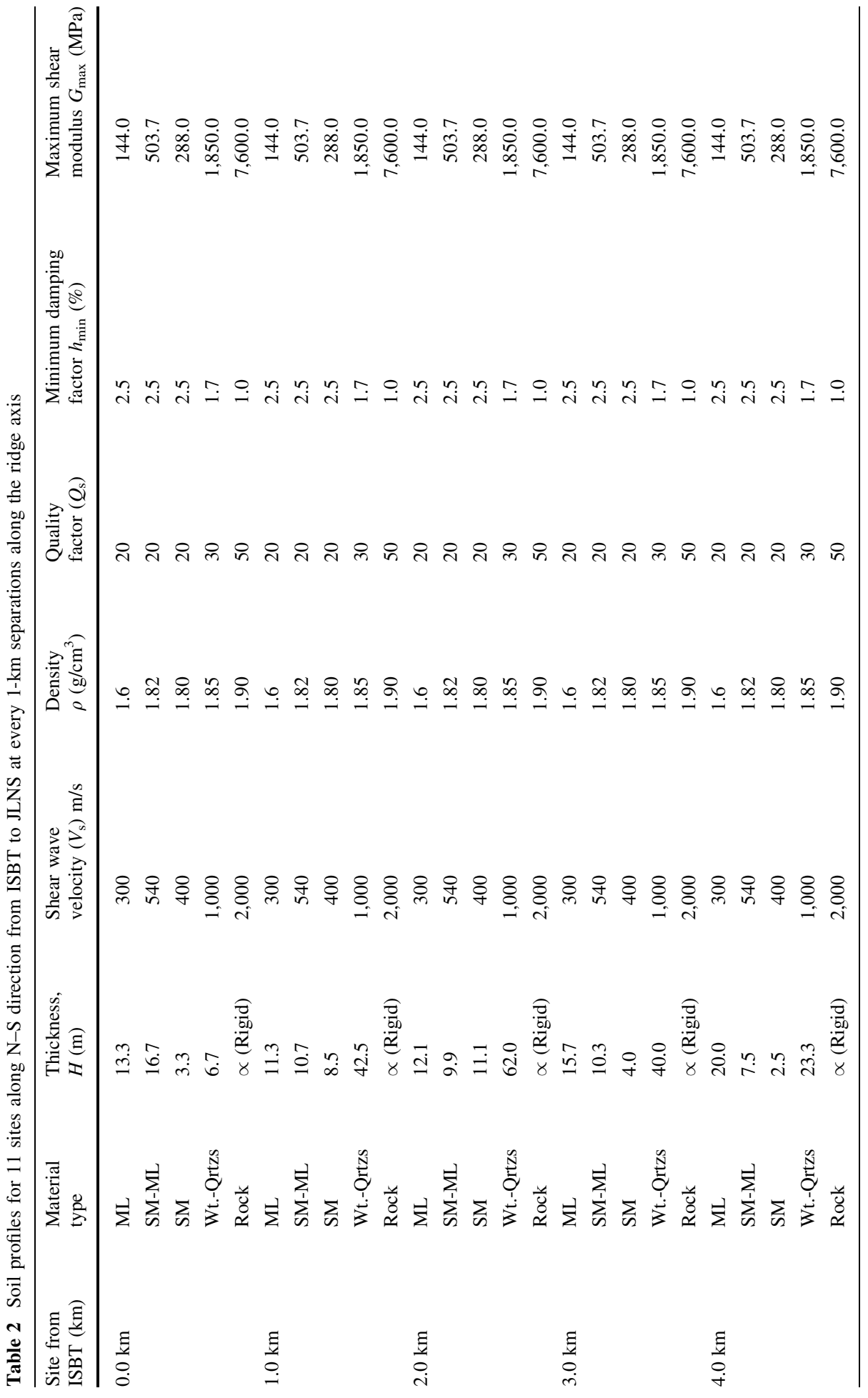




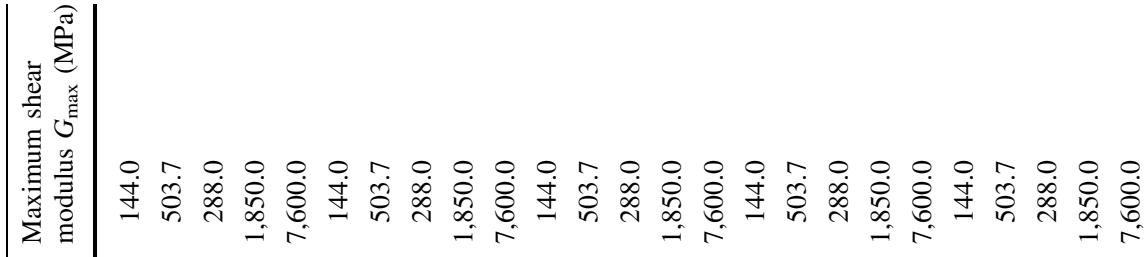

nุ

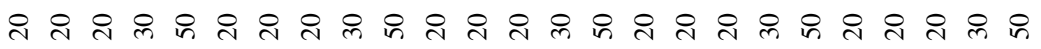

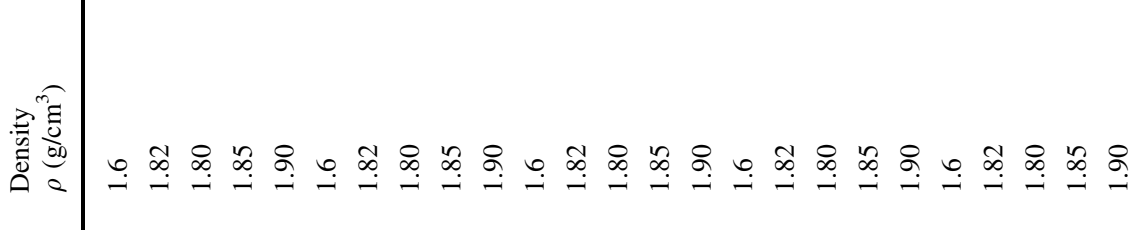

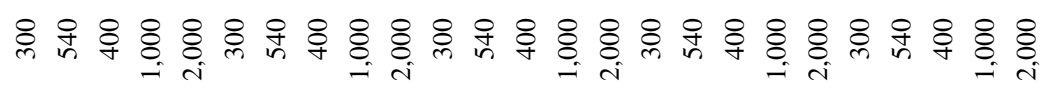

总

窟蓄

$\stackrel{\infty}{\Xi}$

$\overbrace{i}^{\infty}$

$3 \stackrel{0}{2}$

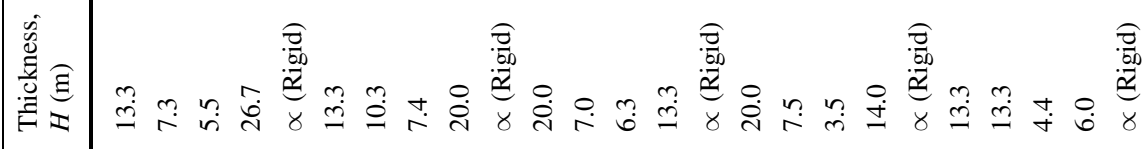

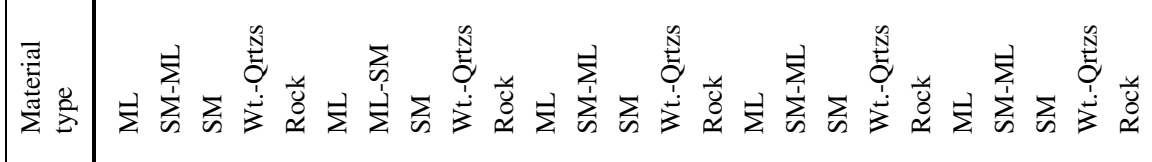

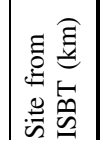

$\frac{\text { g }}{0}$

$\stackrel{g}{\circ}$

$\frac{\xi}{\infty}$

$\frac{5}{3}$ 


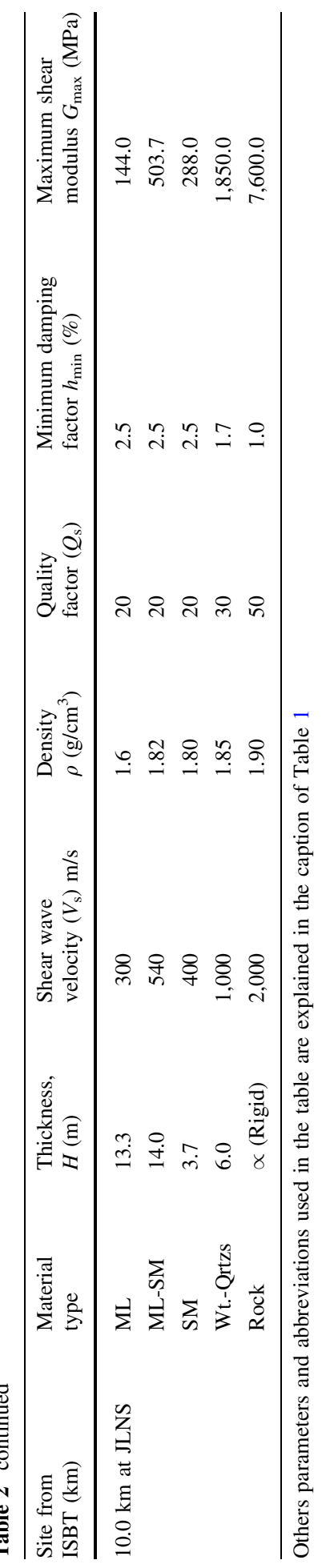


Table 3 The table represents the average shear wave velocity up to $30 \mathrm{~m}$ depth, $\overline{V_{\mathrm{s}}}(30)$ at 25 sites for two profiles, that is, sl. no. 1 to 11 for $\mathrm{N}-\mathrm{S}$ profile and 12-25 for $\mathrm{E}-\mathrm{W}$ profile, respectively

\begin{tabular}{llll}
\hline S1 No. & Latitude $\left(^{\circ}\right)$ & Longitude $\left(^{\circ}\right)$ & $\overline{V_{\mathrm{s}}}(30) \mathrm{m} / \mathrm{s}$ \\
\hline 1 & 28.701 & 77.202 & 359 \\
2 & 28.691 & 77.195 & 381 \\
3 & 28.682 & 77.211 & 347 \\
4 & 28.673 & 77.184 & 369 \\
5 & 28.662 & 77.185 & 345 \\
6 & 28.653 & 77.201 & 419 \\
7 & 28.641 & 77.175 & 366 \\
8 & 28.632 & 77.215 & 315 \\
9 & 28.623 & 77.192 & 336 \\
10 & 28.612 & 77.189 & 375 \\
11 & 28.603 & 77.222 & 377 \\
12 & 28.681 & 77.213 & 388 \\
13 & 28.675 & 77.201 & 398 \\
14 & 28.682 & 77.192 & 349 \\
15 & 28.665 & 77.183 & 387 \\
16 & 28.681 & 77.171 & 368 \\
17 & 28.685 & 77.162 & 364 \\
18 & 28.675 & 77.153 & 372 \\
19 & 28.682 & 77.142 & 319 \\
20 & 28.675 & 77.131 & 341 \\
21 & 28.685 & 77.123 & 346 \\
22 & 28.675 & 77.114 & 359 \\
23 & 28.685 & 77.102 & 365 \\
24 & 28.680 & 77.091 & 333 \\
25 & 28.685 & 77.082 & \\
\hline & & & \\
\hline
\end{tabular}

using the empirical relation of shear wave velocity $\left(V_{\mathrm{s}}\right)$ and density $(\rho)$. Average velocity up to $30 \mathrm{~m}$ is calculated for site classification for all 25 sites shown in Table 3 .

A total duration of earthquake signal of $40.96 \mathrm{~s}$ with cutoff frequency of $20 \mathrm{~Hz}$ was used for the analysis (Fig. 7). The trace of observed earthquake has been digitized over sampling interval of $\Delta t=0.005 \mathrm{~s}$ and obtained 8,192 data points were used in the ELM. The layer parameters, that is, thickness, $V_{\mathrm{s}}, G_{\max }, h(\%)$ and $G_{0}$ for five respective layers including half space were used to yielding amplification factors for different layers. The equivalent method is based on the principal stress and that is proportional to the strain. The effective stress is read off from the stress-strain curve for 0.65 times of strain value. The acceleration time history is put at weathered quartzite rock for which the shear velocity is $1,000 \mathrm{~m} / \mathrm{s}$ comparable with that of an engineering bed rock. The engineering bedrock is defined as B class site (Table 4) with shear wave velocity varying between 760 and $1,500 \mathrm{~m} / \mathrm{s}$ as per the National Earthquake Hazard Reduction Program (NEHRP). Figure 3 shows that seismic waves, generated due to an earthquake through faulting at seismological bedrock depth, are propagating upward with high shear wave velocity $3,500 \mathrm{~m} / \mathrm{s}$ and further penetrating the engineering bedrock at velocity between 760 and $1,500 \mathrm{~m} / \mathrm{s}$. The propagating seismic wave encountered both reflection and refraction when it reaches the very low-velocity fluvial deposits near the surface (i.e., $30 \mathrm{~m} \mathrm{depth}$ ). This was used as input ground motion for all the layers in the analysis. Finally, a high amplitude 
Fig. 7 Observed acceleration time history at Seismic Ridge Observatory (SOR) sites in NCT Delhi during incidence of 25 November 2007 an earthquake with magnitude $M_{\mathrm{L}} 4.3$ occurred at the Delhi-Haryana Border. Total duration of recording trace was about $40.96 \mathrm{~s}$, and the digitized sampling points were 8,192 (sample interval $0.005 \mathrm{~s}$ ) used in this study. The unit of acceleration is in $g$ (gravity)

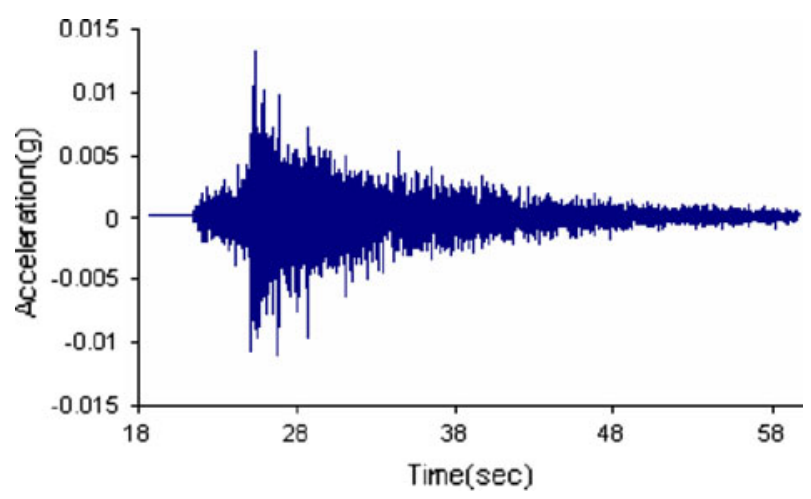

Table 4 This illustrates the NEHRP Site Classes based on $\overline{V_{\mathrm{s}}}(30)$, the average shear wave velocity up to $30 \mathrm{~m}$ depth (after BSSC, 2001)

\begin{tabular}{ll}
\hline Site class & Range of $\overline{V_{\mathrm{s}}}(30)(\mathrm{m} / \mathrm{s})$ \\
\hline A & $1,500<\overline{V_{\mathrm{s}}}(30)$ \\
B & $760<\overline{V_{\mathrm{s}}}(30) 1,500$ \\
C & $360<\overline{V_{\mathrm{s}}}(30) 760$ \\
D & $180<\overline{V_{\mathrm{s}}}(30) 360$ \\
E & $\overline{V_{\mathrm{s}}}(30)<180$ \\
\hline
\end{tabular}

In this study, two site classes were identified as Site class $\mathrm{C}\left(365 \mathrm{~m} / \mathrm{s} \leq \overline{V_{\mathrm{s}}}(30) \leq 420 \mathrm{~m} / \mathrm{s}\right)$ at Delhi ridge axis and site class $\mathrm{D}\left(315 \mathrm{~m} / \mathrm{s} \leq \overline{V_{\mathrm{s}}}(30)<365 \mathrm{~m} / \mathrm{s}\right)$ beyond the Delhi ridge axis

and longer duration waveform at ground surface caused high-velocity contrast associated with loose alluvium deposits overlying engineering bedrock depth was obtained. Similar procedure was followed for evaluating soil responses at all sites.

\section{Results}

The site amplification factor was studied for the frequency ranges from $0.1 \mathrm{~Hz}$ (low frequency) to $20 \mathrm{~Hz}$ (high frequency). A combined plot of amplification verses frequency factor for all 11-sites along North-South profile and 14-sites along East-West profile are shown in Fig. 8, respectively. Variation of amplification factor peak frequency is noted for both the North-South and East-West profiles. We also assessed the Curve Topology (shape) and found similar patterns for sites located at 1-km and 2-km south of ISBT (Fig. 9b, c), and further for sites located at 5-km and 6-km south of ISBT (Fig. 9f, g). This has reduced the 11 sites responses into main 3 classes as denoted by type-I (Fig. 9a, d, e, h-k), type-II (Fig. 9b, c) and type-III (Fig. 9f, g). Similar classification was done for responses along the East-West profiles (Fig. 8), and this has reduced the 14 generic ground conditions into 5 basic ground amplification patterns as designated by IV, V, VI, VII, and VIII (Fig. 10a-e), respectively. This has altogether has reduced 25-sites responses into 8 basic types of curve topology (Table 5).

The varied amplification factors between 3.2 and 5.9 with peak frequency changes of 1.2-5.3 Hz allowed us to establish the an empirical relation between amplification factors 


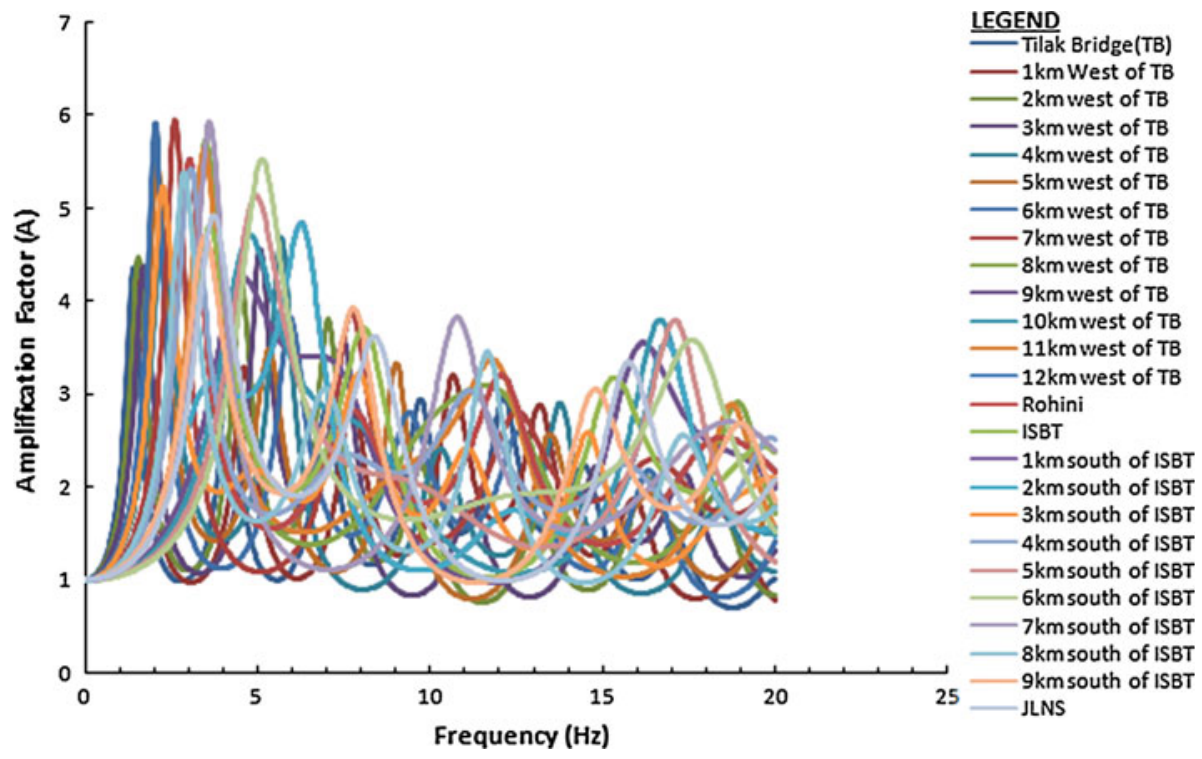

Fig. 8 The combined plot illustrating the amplification factor with respect to frequency along E-W and $\mathrm{N}-\mathrm{S}$ profiles for a total of 14 and 11 sites with 1-km separation, respectively

and peak frequencies as $A=0.36 f+3.60$ for the entire study area (Fig. 11). The established amplitude-frequency relationship may be useful for the engineering design, and moreover, someone can predict the soil amplification using peak frequency or ground motion period computed from seismic microzonation map for a particular site. This means that the ground amplification will be more at high frequency for deep alluvium deposit and vice versa. Figure 12a indicates a spatial variation of peak amplification factors over the study area. A maximum amplification factor of 5.9 is found in the deeper alluvium site and comparative low amplification of 3.2 obtained at the rock site. These observations clearly correlate with those of Iyanger (2000), Parvez et al. (2004) and Rao and Satyam (2005) for the Delhi area. Figure 12b indicates the spatial variation of predominant periods $T$ for the study area. A maximum predominant period of $0.64 \mathrm{~s}$ was observed on thick alluvium soil that decreases toward Delhi ridge and becomes minimum of $\sim 0.14 \mathrm{~s}$ near the ridge axis.

The computed average shear wave velocity for $30 \mathrm{~m}$ depth soil column $\left[\overline{V_{\mathrm{s}}}(30)\right]$ has demarcated the minimum sites over the study area as per National Earthquake Hazard Reduction Program. Table 4 shows the classification of $\overline{V_{\mathrm{s}}}(30)$ for different 25 locations. These data were further used for the mapping of $\overline{V_{\mathrm{s}}}(30)$ at contour interval of $5 \mathrm{~m} / \mathrm{s}$ (Fig. 12c). $\overline{V_{\mathrm{s}}}(30)$ varies between 315 and $419 \mathrm{~m} / \mathrm{s}$. This allowed us to identify two site classes (1) site class $\mathrm{C}$, whose $\overline{V_{\mathrm{s}}}(30)$ varies from 365 to $419 \mathrm{~m} / \mathrm{s}$, and the area is demarcated by dotted line encompassing the ridge. While site class $\mathrm{D}$, whose $\overline{V_{\mathrm{s}}}(30)$ varies from 315 to $365 \mathrm{~m} / \mathrm{s}$, isolates thick alluvium sites beyond the ridge axis.

\section{Discussion and conclusions}

The high-resolution amplification factors determined over a very close 1-km spacing using equivalent linear method led to understanding the frequency-dependent variation of soil 
(a) East-west profile at ISBT

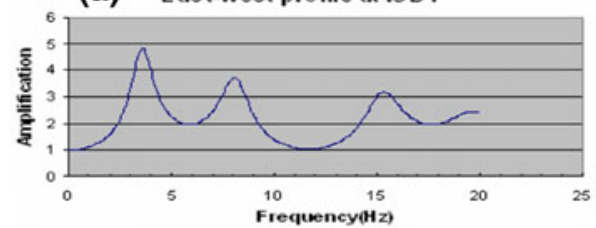

(c)

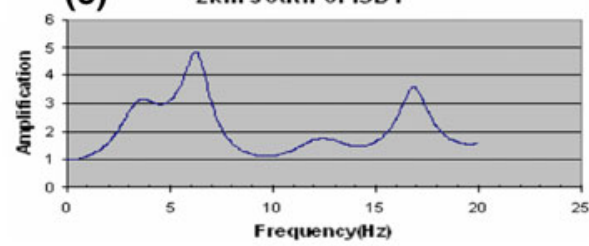

(e)

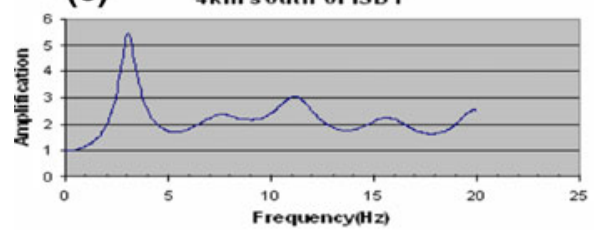

(g)

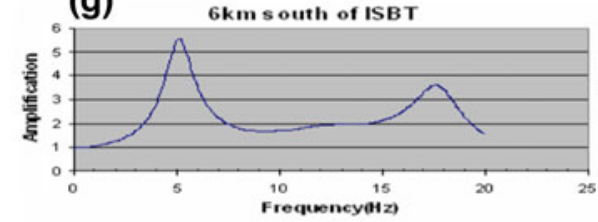

(i) $10 \mathrm{~km}$ south of ISB T at JLNS
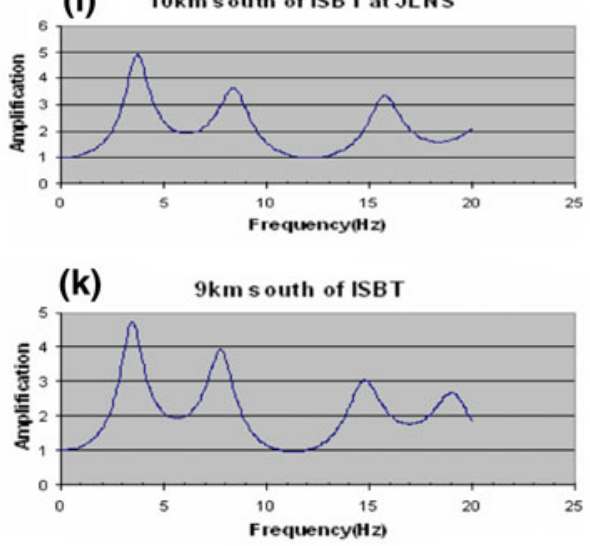
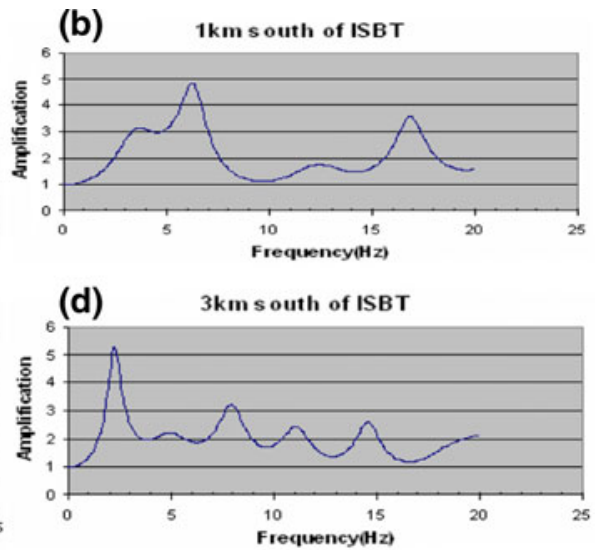

(f)

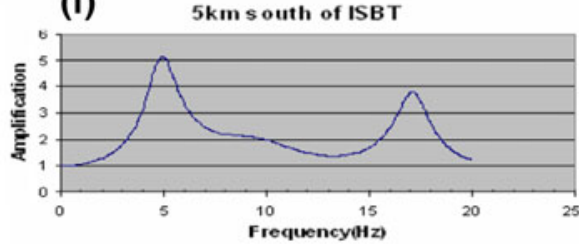

(h)
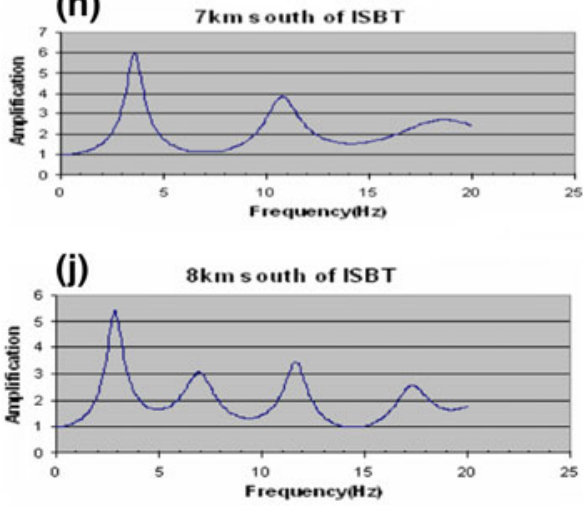

Fig. 9 Plots represent the individual site amplification with respect to frequency along N-S profile starting from ISBT, that is, $\mathbf{a}-\mathbf{k}$ for a total 11 sites

parameter. The amplification factors varying from 3.2 to 5.9 for the entire area over the frequency range $0-20 \mathrm{~Hz}$ is well corroborated with the results of Iyanger (2000) as reported for two soil sites in Delhi using Himalayan earthquake. The empirical linear 

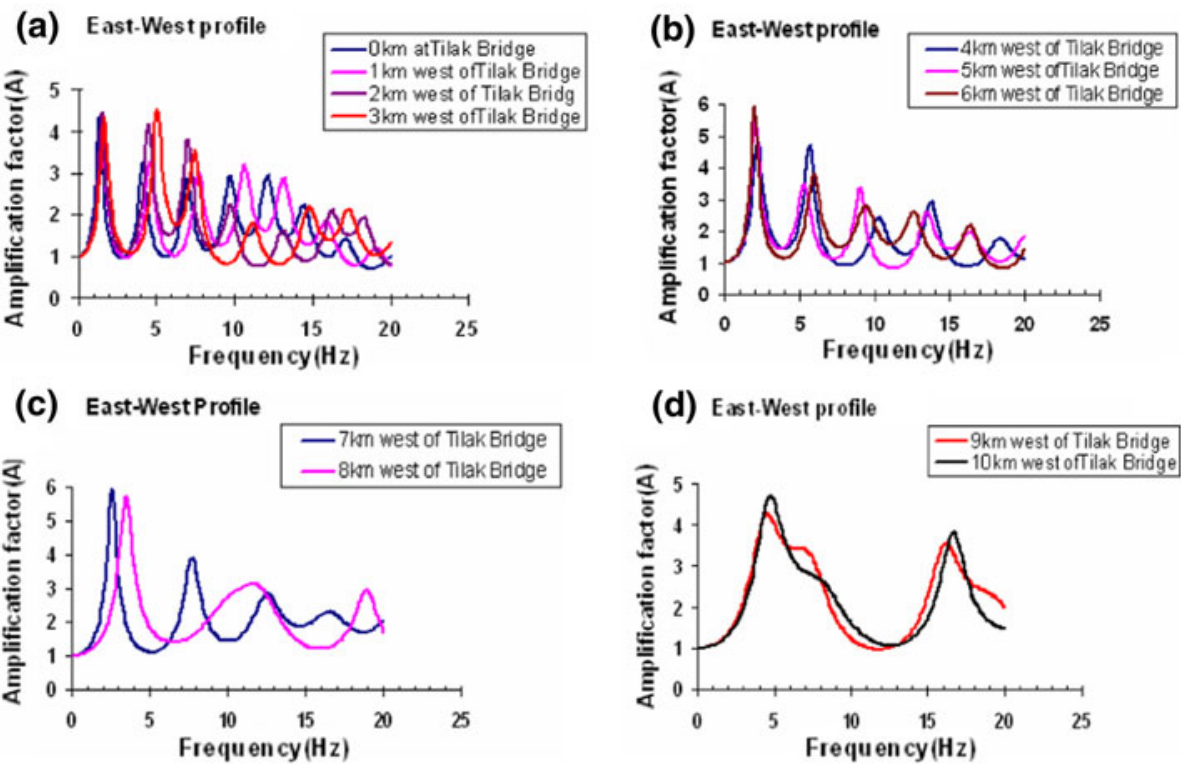

(d) East-West profile

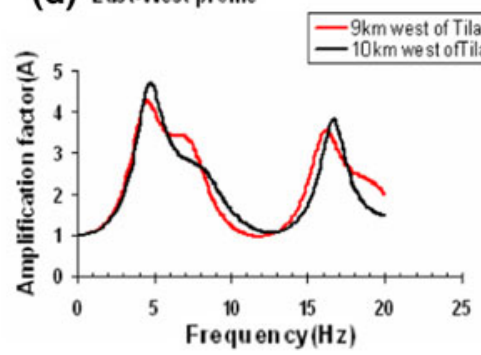

(e) East-West Profile

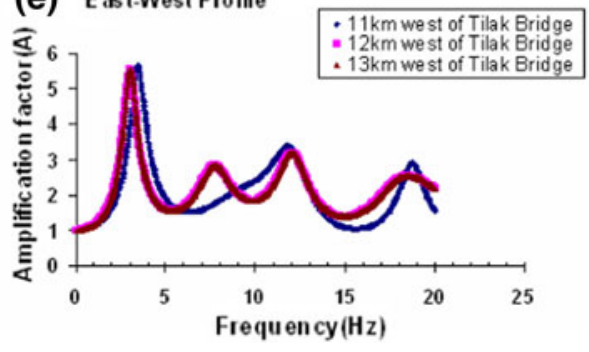

Fig. 10 Plot illustrating the relative variation of amplification factors with frequency in major 5-classes selected on the similar curve pattern obtained from ELM for east-west profile

relationship between amplification factors and frequency (i.e., from 1.2 to $5.1 \mathrm{~Hz}$ ) so derived for all soil classes over the area may have a direct application for sites characterization. The present study also reveals that thicker soil deposit away from the Delhi ridge axis produces more amplification with respect to engineering bedrock depth and at relatively less frequency contains found along the ridge axis. Mukhopadhyay et al. (2002) and Parvez et al. (2004) reported the soil amplification is more at soil sites in Delhi than that of ridge rock sites. The empirical equation (i.e., $A=0.36 f+3.60$ ) may be used to improve the building code over the study area.

The present analysis of $\overline{V_{\mathrm{s}}}(30)$ accounts for better site characterization in Delhi area. Figure 10 illustrates the variation of average velocity of shear wave up to $30 \mathrm{~m}$ depth for the study area. The minimum contour value of $315 \mathrm{~m} / \mathrm{s}$. is noted near the western part and increases toward NE-SW direction and decreases toward the eastern part of the study area. The $\overline{V_{\mathrm{s}}}(30)$ lies between 365 and $425 \mathrm{~m} / \mathrm{s}$. near the central part of the study area and oriented along $\sim \mathrm{NE}-\mathrm{SW}$ direction apparently associated with the Delhi ridge. $\overline{V_{\mathrm{s}}}(30)$ ranges from 390 to $420 \mathrm{~m} / \mathrm{s}$ for sites at ISBT, SOR, NDLS, and Boat Club those lie on exposed weathered rock. A relatively low $\overline{V_{\mathrm{s}}}(30)$ was identified at SJRD, JLNS, Patel 


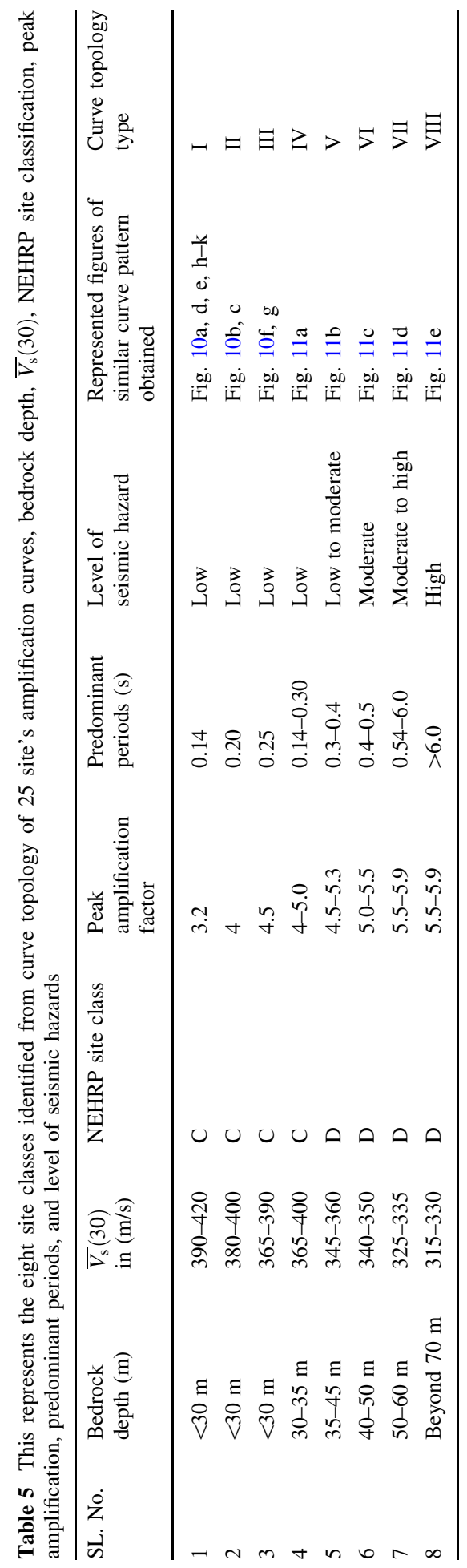


Road, CP and Push Road where the ridge becomes weathered, and very low $\overline{V_{\mathrm{s}}}(30)$ ranges from 315 to less than $360 \mathrm{~m} / \mathrm{s}$ indicates the fresh soil deposit away from the ridge axis. The closure contour center of low $\overline{V_{\mathrm{s}}}(30)$ values was correlated with a small basin structure. The precise identification of such small existing basins or west deposit sites is very important due to earthquake point of view.

The reconstructed seismic zoning maps involving the peak amplification factors and predominant periods (Fig. 12a, b) for Greater Delhi area provides the basis for site-specific risk analysis. This further may assist in the mitigation of earthquake damages. We thus may infer that the areas near the Delhi ridge axis are safer from earthquake damages that the areas away from it and seismically more hazardous. This entire research work may provide a part of guidelines for the future construction of buildings by the engineers over the study area. These results can also be extrapolated and applicable to the other part of NCT Delhi, provided the lithological information up to $30 \mathrm{~m}$ depth for all the 25 sites is more or less extendable.

\section{Limitations of the methodology}

The soil parameters vary with the thickness of soil deposits, geological ages, and type of lithological deposition (e.g., sand, clay, and silt). Hence, the more detail identification of geological and geomorphic features by generating high-resolution map over the study area may vary with the present analysis. The engineering bedrock depth is another important parameter for geotechnical soil response analysis, and thus, a precise demarcation of engineering bedrock depth is needed to exact soil responses. The more detailed geotechnical and geophysical study may improve the result. The equivalent linear method (ELM) is applicable only for the strain ranges from $10^{-4}$ to $10^{-2}$. The effective stress is calculated from the stress-strain curved for 0.65 time of strain value. The present results were evaluated from weak ground motion for earthquake magnitude $M_{\mathrm{L}} 4.3$ at epicentral distance of $\sim 20 \mathrm{~km}$ from the source, which may differ during very strong ground motion generated by large earthquake at the same source location. The predictive parameters evaluated by ELM may be violated from the actual one during nonlinear behavior of the soil due to strong ground motion.

To estimate bedrock characteristics by 1D model and thickness of the soil by regression method have become a state-of-an-art technique as recently carried out by Chowdhuri et al. (2009) for Krishnagar Area of Nadia District, West Bengal, India. It is so because 1D

Fig. 11 Plot showing the correlation of peak frequency with amplification factors for all categorized soil type at different sites for maximum frequency of $5.1 \mathrm{~Hz}$ and amplification factor 5.9

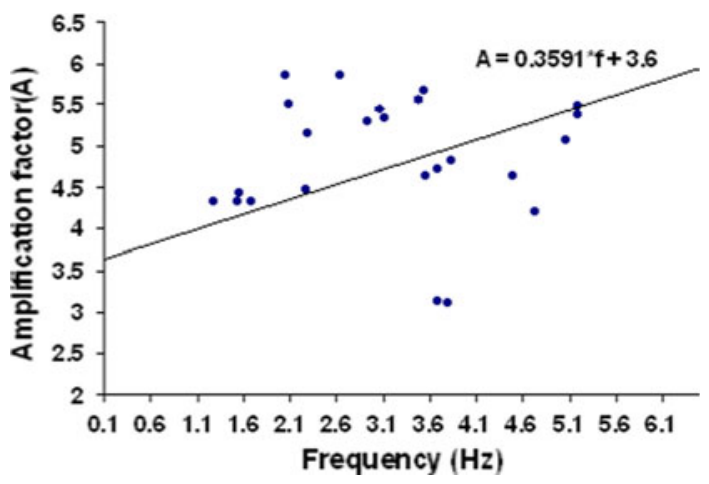




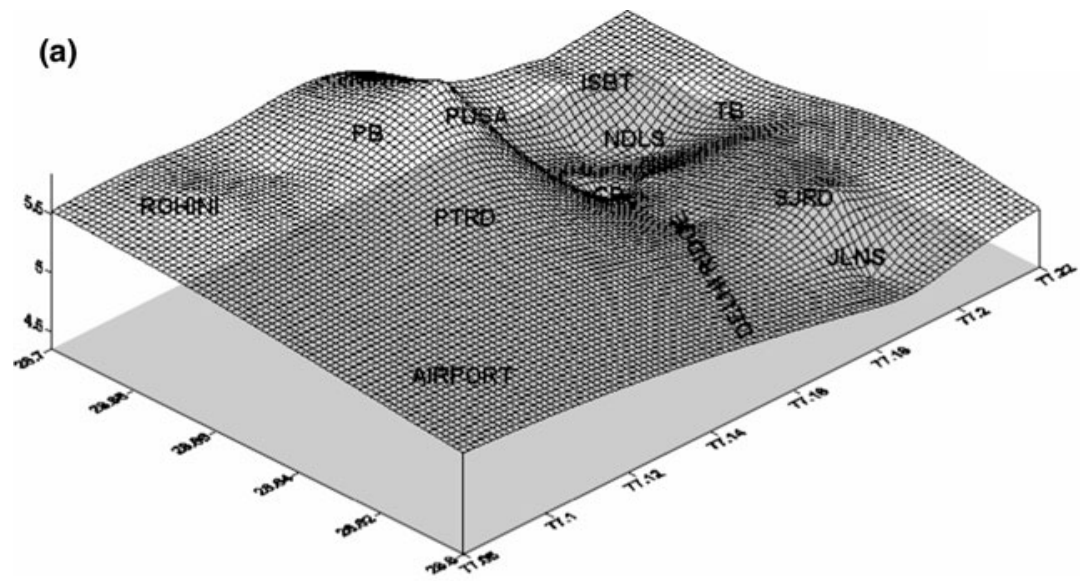

(b)

Period (s)

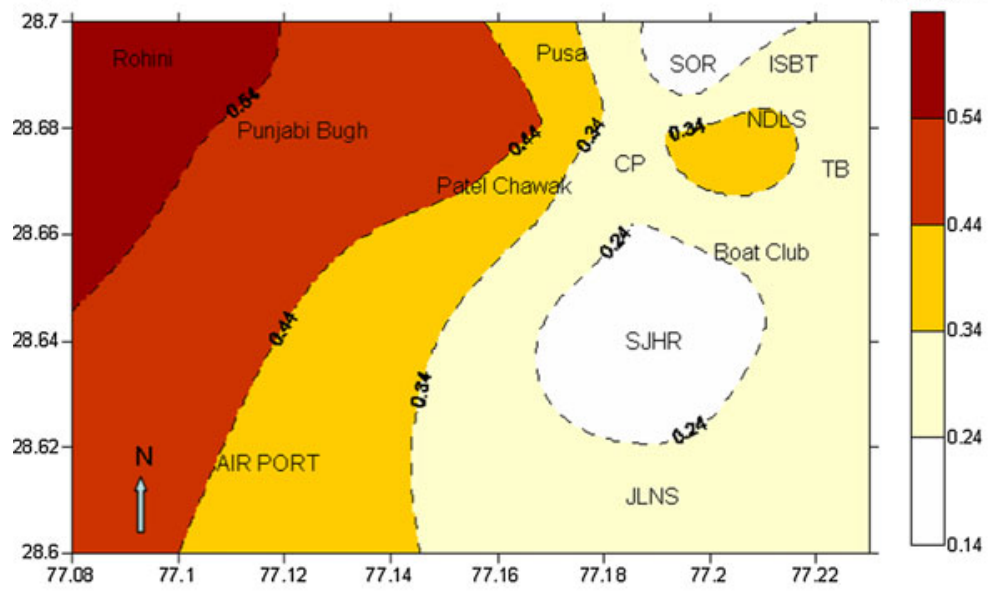

(c)

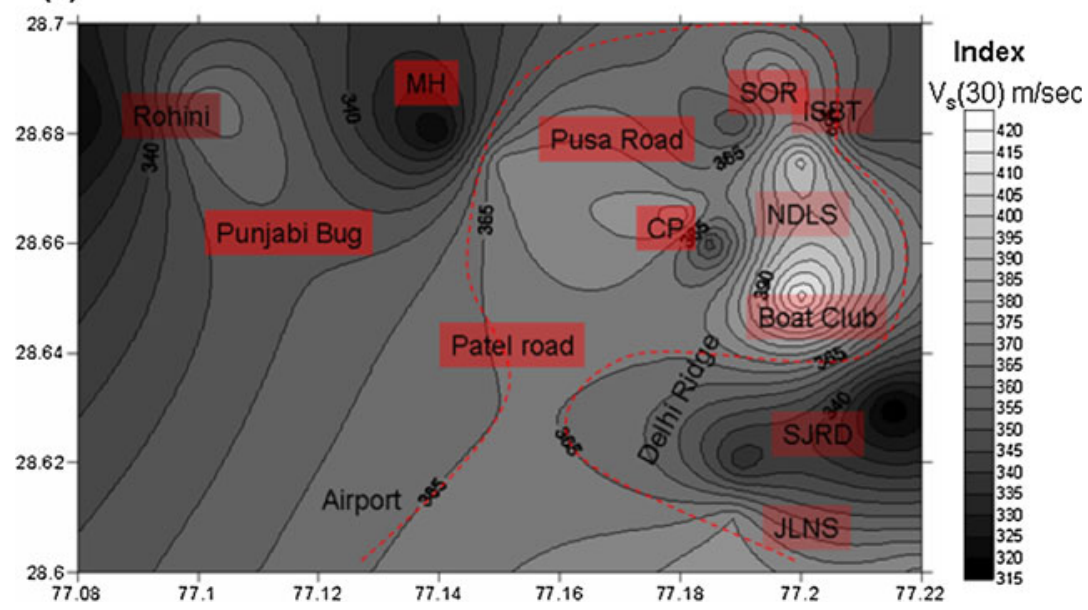


Fig. 12 a Map shows the variation of amplification factors in respect of sites. Amplification is less in rock sites along ridge axis than in the thick alluvium sites lies in the western part of the ridge. b Seismic zoning map of Greater Delhi reconstructed based on predominant period at sites obtained from this study. c Contour map showing the variation of average velocity of shear wave up to $30 \mathrm{~m}$ depth for the study area. The contour interval $5 \mathrm{~m} / \mathrm{s}$ is chosen. The minimum and maximum value of $\overline{V_{\mathrm{s}}}(30)$ ranges from 315 to $419 \mathrm{~m} / \mathrm{s}$. The minimum contour values were recorded at the western part of the study area and apparently increases from NE to SW direction and decreases toward its eastern part. The $\overline{V_{\mathrm{s}}}(30)$ ranges from 365 to $419 \mathrm{~m} / \mathrm{s}$. are noted in the central part area and oriented along NE-SW direction and moreover is associated with the Delhi ridge. The sites at ISBT, SOR, NDLS, and Boat Club lay on exposed weathered rock sites whose $\overline{V_{\mathrm{s}}}(30)$ ranges from 390 to $419 \mathrm{~m} / \mathrm{s}$. Note the comparatively low $\overline{V_{\mathrm{s}}}(30)$ on Delhi ridge sites, that is, at SJRD, JLNS, Patel Road, CP, and Push Road because of weathered rocks and very low $\overline{V_{\mathrm{s}}}(30)$ ranges from 315 to less than $360 \mathrm{~m} / \mathrm{s}$ indicates the fresh soil deposit located away from ridge axis. The closure contours with deceasing value toward its center indicate small basin structure

ground response analyses are based on the assumption that all boundaries are horizontal and the response of a soil deposit is predominantly caused by $\mathrm{SH}$-wave propagating vertically from the underlying bedrock, the soil and bedrock surface assumed to be extending infinitely in the horizontal direction. This process eliminates the influence of the source effects. The frequency characteristics of the amplification factor for 1D two-layered model can be obtained by solving a simple wave equation of sinusoidal input. The amplification may help to estimate thickness of soft soil. This approach may be augmented in future study to understand the soil characteristics of the area. Similar approach has been made by Chowdhuri et al. (2011) for the Agartala city, capital of Tripura state of India.

Acknowledgments First author is thankful to the Director General of Meteorology, Dr. (AVM) Ajit Tyagi for his valuable support and facility provided to carrying out this study. First author also acknowledges Dr. B. K. Rastogi, Director, Institute of Seismological Research (ISR), Gandhinagar, Gujarat, India for critical discussion and suggestions during its presentation in the International seminar entitled "The 2001 Bhuj earthquake and Advances in Earthquake sciences-AES2011" organized by ISR Gujarat, India. We are thankful to Dr. Thomas Glade, Journal of Natural Hazards for suggesting modifications, which improved our manuscript. Authors are thankful to two anonymous reviewers for constructive comments and suggestions that further helped improve the manuscript.

Open Access This article is distributed under the terms of the Creative Commons Attribution License which permits any use, distribution, and reproduction in any medium, provided the original author(s) and the source are credited.

\section{References}

Agrawal SK, Chawla J (2006) Seismic hazard assessment for Delhi region. Curr Sci 91(12):1717-1724

Benuska L (1990) Loma Prieta Earthquake of October 17, 1989. Reconnaissance Report, Supplement to Earthquake Spectra vol 6, pp 450

Boore DM, Joyner WB, Fumal TE (1997) Equations for estimating horizontal response spectra and peak acceleration from western North American earthquakes: a summary of recent work. Seismol Res Lett 68:128-153

Borcherdt RD, Glassmoyer G (1992) On the characteristics of local geology and their influence on ground motions generated by the Loma Prieta earthquake in the San Francisco Bay region, California. Bull Seismol Soc Am 82:603-641

Building Seismic Safety Council (BSSC) (2001) NEHRP recommended provisions for seismic regulations for new buildings and other structures, 2000 edition. Part 1: provisions. Prepared by the Building Seismic Safety Council for the Federal Emergency Management Agency (Report FEMA 368), Washington

Chowdhuri SN, Singh OP, Mishra OP, Kayal JR (2009) Microzonation study from ambient noise measurement for assessing site effects in Krishnanagar area and its significance with the damage pattern of the September 241996 earthquake (Ms 4.3). Indian Minerals 62:183-192 Special Issues 
Chowdhuri SN, Singh OP, Majumdar RK (2011) Site response studies in Agartala Urban agglomeration. Nat Hazards 59:329-345

Dasgupta S, Pande P, Ganguly D, Iqbal Z, Sanyal K, Venkatraman NV, Dasgupta S, Sural,B, Harendranath, L, Mazumdar K, Sanyal S, Roy A, Das LK, Misra PS, Gupta H (2000) Seismotectonic atlas of India and its environs. In: Narula PL, Acharyya SK, and Banerjee J (eds) Geol Surv India Special Publ no 59, pp 87

Dobry R, Borcherdt RD, Crouse CB, Idriss IM, Joyner WB, Martin GR, Power MS, Rinne EE, Seed RB (2000) New site coefficients and site classification system used in recent building seismic code provisions. Earthq Spectra 16:41-67

Erdik M (1987) Site response analysis, in strong ground motion seismology. In: Erdik MO, Toksoz MN (eds) D. Reidel Publishing Company, Dordrecht, The Netherlands, pp 479-534

Finn WDL (1991) Geotechnical engineering aspects of microzonation. In: Proceedings of the fourth international conference on seismic zonation, Stanford, California, vol 1, pp 199-259

Fukushima Y, Midorikawa S (1994) Evaluation of site amplification factors based on average characteristics of frequency dependent $Q^{-1}$ of sedimentary strata. J Struct Constr Eng AIJ 460:37-46

Gutenberg B (1957) Effects of ground on earthquake motion. Bull Seismol Soc Am 47:221-250

Hardin BO, Drnevich VP (1972a) Shear modulus and damping in soils measurement and parameter effects. J Soil Mech Found Div ASCE 98:603-624

Hardin BO, Drnevich VP (1972b) Shear modulus and damping in soils: design equations and curves. J Soil Mech Found Div ASCE 98:667-692

Haskell N (1960) Crustal reflection of plane SH waves. J Geophys Res 65:4147-4150

Hukku BM (1964) Report on geological investigations of the minor earthquakes around Sonepath and Punjab. G S I, unpublished

Iyanger RN (2000) Seismic status of Delhi megacity. Curr Sci 78(5):568-574

Iyengar RN (1999) Earthquakes in Ancient India. Curr Sci 77:827-829

Iyengar RN, Ghosh S (2004) Microzonation of earthquake hazard in Greater Delhi area. Curr Sci $87: 1193-1202$

Joshi GC, Sharma ML (2011) Strong ground-motion prediction and uncertainties estimation for Delhi, India. Nat Hazards. doi:10.1007/s11069-011-9783-y

Kanai K, Takahasi R, Kawasumi H (1956) Seismic characteristics of ground. In: Proceedings of the world conference on earthquake engineering, Berkeley, California, 31-1-31-16

Kramer SL (1996) Geotechnical earthquake engineering. Prentice Hall, Inc., Upper Saddle River, p 653

Mahajan AK, Thakur VC, Sharma ML, Chauhan M (2010) Probabilistic seismic hazard map of NW Himalaya and its adjoining area, India. Nat Hazards 53:443-457

Mohammadioun B, Pecker A (1984) Low-frequency transfer of seismic energy by superficial soil deposits and soft rocks. Earthq Eng Struct Dyn 12:537-564

Mohanty WK, Walling MY, Nath SK, Pal I (2007) First order seismic microzonation of Delhi, India using geographic information system (GIS). Nat Hazards 40(2):245-260

Mukhopadhyay S, Pandey Y, Dharmaraju R, Chauhan PKS, Singh P, Dev A (2002) Seismic microzonation of Delhi for ground-shaking site effects. Curr Sci 82(7):877-881

Murphy JR, Davis AH, Weaver NL (1971) Amplification of seismic body waves by low-velocity surface layers. Bull Seismol Soc Am 61:109-145

Oldham T (1883) A catalogue of Indian earthquakes from earliest times to the end of A.D. 1869. Mem GSI $129(\mathrm{X}): 1883$

Parvez I, Vaccari F, Panza GF (2004) Site-specific microzonation study in Delhi metropolitan city by 2-d modeling of SH and P-SV waves. Pure Appl Geophys 161:1165-1185

Rao KS and Satyam DN (2005) Seismic microzonation studies for Delhi region. In: Symposium on seismic hazard analysis and microzonation, 23-24 Sept, Roorkee, pp 213-234

Schnabel PB, Lysmer J, Seed HB (1972) SHAKE: a computer program for earthquake response analysis of horizontally layered sites. Report No UCB/EERC 72/12, Earthquake Engineering Research Center, University of California, Berkeley

Seed HB, Idriss IM (1969) Influence of soil conditions on ground motions during earthquakes. J Soil Mech Found Div ASCE 95:99-137

Seed HB, Idriss IM (1970) Soil moduli and damping factors for dynamic response analysis. Report No. EERC 70-10, Earthquake Engineering Research Center, University of California, Berkeley

Seed HB, Romo MP, Sun JI, Jaime A, Lysmer J (1988) The Mexico Earthquake of September 19, 1985 relationships between soil conditions and earthquake ground motions. Earthq Spectra 4:687-729

Sharma S (1965) Report on the investigation into probable causes of earthquakes, tremors near Sonepat and Punjab. Unpublished 
Sharma ML, Wason HR, Dimri R (2003) Seismic zonation of the Delhi region for Bedrock ground motion. Pure Appl Geophys 160:2381-2398

Shearer PM, Orcutt JA (1987) Surface and near-surface effects on seismic waves theory and borehole seismometer results. Bull Seismol Soc Am 77:1168-1196

Singh M (1964) The tribute Oct 15

Srivastava LS, Somayajulu JG (1966) The seismicity of area around Delhi. In: Third symposium on earthquake engineering, UOR Roorkee, pp 4-6

Tandon AN, Choudhury HM (1966) A report on the seismicity studies by the India Meteorological Department. Third symposium on earthquake engineering Roorkee. UOR 1966 Part II, pp 34-43

Wills CJ, Petersen M, Bryant WA, Reichle M, Saucedo GJ, Tan S, Taylor G, Treiman J (2000) A site conditions map for California based on geology and shear wave velocity. Bull Seismol Soc Am 90:S187-S208 